\title{
Pendampingan Dalam Mengenali dan Menyelesaikan Soal Ujian Nasional Berbasis Higher Order Thinking Skills (HOTS)
}

\author{
Fahrurrozi $^{1}$, Nila Hayati ${ }^{2}$, Sri Supiyati ${ }^{3}$, Neny Endriana ${ }^{4}$ \\ 1mas.odji@gmail.com, ${ }^{2}$ hayatisyahdani@gmail.com, ${ }^{3}$ supiyatisambada@gmail.com \\ ${ }^{4}$ nenyendrianaclassb@yahoo.co.id \\ Pendidikan Matematika, Fakultas MIPA, Universitas Hamzanwadi ${ }^{1,2,3,4}$
}

DOI: 10.29408/ab.v1i1.2404

\begin{abstract}
Abstrak: Kegiatan ini dilatar belakangi oleh hasil laporan mahasiswa tentang kondisi pembelajaran matematika dilapangan khususnya didaerah pesisir pantai labuhan haji, selain itu juga hasil kajian dan analisis beberapa dosen tentang fenomena ramainya siswa mengeluh dengan dimunculnya soal-soal kategori high order thinking skill (HOTS) pada ujian nasional tahun 2018 sehingga dirasa perlu untuk dilakukan pendampinga mengenali dan menyelesaikan Soal UN Matematik Kategori HOTS di MTs NW dan MA NW Selayar Kec. Sakra Timur. Adapun tujuan dari kegiatan ini 1) membantu siswa dan siswi MTs NW dan MA NW Selayar dalam mengenal dan menyelesaikan soal UN matematika kategori HOTS, 2) memberikan pengalaman langsung kepada beberapa mahasiswa tentang kondiri riil pendidikan di pesisir pantai Labuhan haji, dan 3) memberikan kesempatan kepada mahasiswa untuk melatih diri dalam berogranisasi dan mengajarkan konsep matematika dengan benar. Proses kegiatan ini meliputi 1) perencanaan, 2) pelaksanaan, dan 3) evaluasi dengan tim dosen dan mahasiswa dan pembuatan laporan. Hasil pendampingan program ini adalah 1) yayasan dan dewan guru merasa terbantu dalam memberikan pemahaman matematika yang benar kepada siswa, 2) 80\% mahasiswa dapat mengenali soal UN Matematika kategori HOTS dan 65\% dapat menyelesaikannya, dan 3) mahasiswa merasa percaya diri dan lebih semangat lagi untuk belajar karena diberikan kesempatan langsung merasakan bagaimana permasalahan dan pembelajaran di kelas. Dengan dilakukan pendampingan, kemampuan siswa MTs dan MA NW Selayar menyelesaikan soal UN Matematika berbasis HOTS mengalami peningkatan dari sebelumnya

Kata Kunci : Abdisomat, UN, HOTS
\end{abstract}

\section{PENDAHULUAN}

Matematika memegang peranan penting dalam kehidupan manusia. Banyak yang telah disumbangkan Matematika bagi perkembangan peradaban manusia. Kemajuan Sains dan teknologi yang begitu pesat tidak lepas dari peranan Matematika. Boleh dikatakan, Matematika adalah landasan utama Sains dan teknologi. Dengan demikian menguasai Matematika merupakan salah satu jalan utama menuju tumbuh berkembangnya ilmu pengetahuan dan teknologi di negeri ini. Oleh sebab itu, pendidikan Matematika telah mulai diajarkan dari sejak Pendidikan Anak Usia Dini (PAUD) hingga pendidikan di perguruan tinggi agar generasi muda Indonesia mampu berkreasi dalam bidang teknologi sebagai bentuk adaptasi perkembangan zaman.

Namun sangat disayangkan, penguasaan pendidikan matematika di Indonesia masih jauh dari kata berhasil. Hal ini terlihat dari peringkat Indonesia pada hasil penilaian dari Trends International Mathematics and Science Study (TIMMS) di tahun 2015, memposisikan Indonesia pada posisi 45 dari 50 negara yang ikut (Mullis, et all, 2015; Rahmawati, 2016). Hasil 


\section{ABSYARA: JURNAL PENGABDIAN PADA MASYARAKAT BIDANG PENDIDIKAN, SAINS, DAN TEKNOLOGI}

Vol. 1 No. 1, Juli 2020, Hal. 10-15

ini tidak menunjukkan banyak perubahan pada setiap keikutsertaannya dalam ajang tersebut. Terbaru hasil penilaian dari Program for International Student Assessment (PISA) tahun 2018 masih jauh dari target yaitu pada aspek membaca target 446 realisasi 371, matematika 427 realisasi 379 dan sains 428 realisasi 396. Dari 78 negara yang ikut, Indonesia berada pada posisi 72 (OECD, 2019).

Hasil prestasi terutama pada ajang TIMSS yang rendah tersebut tentunya disebabakan oleh beberapa faktor. Salah satu factor penyebabnya antara lain karena peserta didik di Indonesia kurang terlatih dalam menyelesaikan soal-soal seperti karakter soal-soal pada TIMSS. Soal-soal pada TIMSS bersifat kontekstual, membutuhkan penalaran, argumentasi, dan kreatifitas yang tinggi dalam menyelesaikannya. Hal ini diperkuat juga dengan pendapat Winataputra (dalam Riadi \& Retnowati, 2014) tenatng penelitian TIMSS yang menunjukkan masih rendahnya prestasi siswa Indonesia dalam matematika, terutama terkait soal-soal Higher Order Thinking Skills (HOTS).

HOTS merupakan keterampilan berpikir yang membutuhkan keterampilan berpikir tingkat tinggi, tidak hanya keterampilan mengingat saja. Seperti yang dikemukakan oleh Anderson \& Krathwol dalam Mandini \& Hartono (2018), indikator untuk mengukur HOTS meliputi keterampilan menganalisis, mengevaluasi, dan menciptakan. Hal serupa juga dikemukakan oleh King, Godson, \& Rohani (2013) menyatakan bahwa di dalam HOTS termuat berpikir kritis, logis reflektiif, metakognisi, dan kreatif.

Keterampilan HOTS yang nantinya dimiliki oleh peserta didik untuk mempersiapkan mereka memenuhi tuntutan kecakapan pada abad 21, dimana peserta didik diharapkan memiliki tingkat berpikir kritis yang tinggi, kreatif, dan berkomuniaksi dengan baik. Hal serupa juga dijelaskan dalam The Partnership for 21st Century Skill (Warisdiono dalam Hamdi, et all, 2018) menjelaskan bahwa pendidikan di dunia harus memfokuskan pada pengembangan 4 kompetensi untuk menghadapi tantangan abad 21 yaitu kreatif, berpikir kritis, komunikasi, dan kolaborasi.

Salah satu reformasi pembelajaran dan penilaian Indonesia saat ini diwarnai dengan diterapknnya pembelajaran dan penilaian berbasis HOTS pada kurikulum 2013. Bahkan soalsoal pada Ujian Nasional sudah berkategori HOTS, dan ini sudah dilaksanakan dari tahun 2017. Akan tetapi kenyataan yang terkadi di sekolah, proses pembelajaran dan kegiatan penilaian belum terlalu focus pada HOTS ini. Terutama dalam kegiatan penilaian, soal-soal yang diberikan oleh guru cenderung lebih banyak menguji aspek ingatan yang kurang melatih keterampilan berpikir tingkat tinggi.

Hal ini juga terjadi pada pembelajaran matematika khususnya di daerah pesisir Labuhan Haji seperti di MTs dan MA NW Selayar. Dari hasil observasi dan wawancara awal yang dilakukan, para guru di sana sebagian besar tidak terlalu memperdulikan HOTS ini, prinsipnya asalkan materinya habis disampaikan. Mereka belum terbiasa memberikan soal-soal yang menuntut tingkat berpikir tinggi karena kemampuan siswa di sekolah secara umum masih di bawah rata-rata. Selain itu mereka belum terlalu familiar dengan istilah HOTS. Apalagi pada Ujian Nasional sekarang ini, terdapat beberapa soal yang berkategori HOTS, para guru 
mengeluhkan bagaimana penyelesainnya dikarenakan kurang terbiasa. Berdasarkan permasalahn tersebut, sehingga dirasakan perlu melakukan kegiatan pendampingan dalam mengenali dan menyelesaikan soal UN pada mata pelajaran Matematika yang berbasis HOTS tersebut.

Adapun tujuan kegiatan ini nantinya, selain memberikan pendampingan dalam mengenali dan menyelesaikan soal UN berbasis HOTS juga memberika pengalaman langsung kepada mahasiswa yang terlibat dalam tim kegiatan ini untuk melihat langsung kondisi nyata pendidikan di pesisir pantai Labuhan Haji

\section{METODE PELAKSANAAN}

\section{Waktu dan tempat}

Kegiatan pengabdian kepada masyarakt ini dilakukan pada bulan Juli sampai Agustus 2019. Lokasi kegiatan di MTs dan MA NW Selayar.

\section{Prosedur Pelaksanaan}

Kegiatan pengabdian kepada masyarakat ini dilakukan melalui serangkaian kegiatan yang melalui proses perencanaan, pelaksanaan, dan evaluasi. Pada tahap perencanaan ini tim dosen dan tim mahasiswa melakukan analisis kebutuhan yang dibutuhkan oleh MTs dan MA NW Selayar. Selain itu juga disiapkan modul, media dan instrumen lainnya yang akan digunakan dalam proses pendampingan.

Pelaksanaan pendampingan dilaksanakan pada pagi dan sore hari sesuai dengan jadwa yang telah ditentukan sebelumnya. Pada pertemuan awal pendampingan, diberikan soal UN sebagai pretest program. Setelah itu dilanjutkan dengan pemberian materi tentang soal-soal berbasis HOTS tersebut. Diawali dari pengenalan apa itu soal-soal berbasis HOTS, bagaimana contoh soal-soal yang termasuk kedalam soal berbasis HOTS, dan diberikan penjelasan bagaimana menyelesaiakan soal-soal berbasis HOTS tersebut. Selanjutnya diadakan posttest pada akhir minggu kedua sebagai bentuk evaluasi serapan materi yang sudah diberikan.

Evaluasi kegiatan pendampingan dilakukan bersama tim dosen dan mahasiswa yang terlibat dalam kegiatan ini. Kegiatan evaluasi ini untuk menilai apakah kegiatan ini berhasil atau tidak dengan memantau kehadiran siswa mengikuti kegiatan pendampingan, keseriusan, respon dan antusiasme mereka selama mengikuti pendampingan. Berikutnya dilanjutkan ke tahapan pelaporan dari semua kegiatan. Pelaporan dimaksuud terkait penyusunan rincian laporan akhir yang memuat detail kegiatan yang telah dilakukan 


\section{HASIL DAN PEMBAHASAN \\ HASIL}

Tabel 1. Data Hasil Tes Siswa

\begin{tabular}{lcccc}
\hline \multicolumn{1}{c}{ Deskripsi } & \multicolumn{2}{c}{ Pretest } & \multicolumn{2}{c}{ Posttest } \\
& MTs & MA & MTs & MA \\
\hline Skor maksimum & 66 & 72 & 87 & 92 \\
Skor minimum & 23 & 27 & 45 & 30 \\
Rata-rata & 48 & 46 & 65 & 60 \\
Standar Deviasi & 5,8 & 4,5 & 7,3 & 6,4 \\
Kategori & rendah & rendah & sedang & sedang \\
Ketuntasan & $42 \%$ & $47 \%$ & $63 \%$ & $61 \%$ \\
\hline
\end{tabular}

Untuk menunjang data tes di atas dilakukan wawancara dengan guru mata pelajaran matematika, beberapa hasil wawancara tersebut adalah: 1) guru belum melakukan secara khusus membahas soal UN matematika kategori HOTS karena mereka lebih fokus kepada soalsoal yang mudah, 2) mereka beranggapan bahwa jika muncul soal kategori HOTS siswa dsarankan untuk melewati atau memilih sembarang saja kemudian fokus pada soal-soal yang mudah, 3) ketika ditanya tentang kesulitan mengajarkan matematika hampir semua guru mengatakan bahwa kesulitan yang dialami adalah motivasi siswa yang lemah dan cenderung takut pada mata pelajaran matematika, dan 4) ketika guru ditanya model pembelajaran yang paling sering digunakan adalah model biasa yaitu penjelasan oleh guru khususnya rumusrumus, kemudian contoh dan latihan yang ditutup dengan pemberian pekerjaan rumah sebagai tugas individu.

Tidak jauh berbeda dengan yang dikemukakan oleh guru, dari hasil wawancara dengan para siswa juga diperoleh hal-hal berikut: 1) ketika ditanyakan tentang strategi menghadapi soal HOTS sebelum dilakukan pendampingan adalah dengan memilih sembarang jawaban kemudian fokus pada soal yang dianggap mudah, 2) hamper semua mereka mengatakan bahwa matematika itu sulit dan tidak menyenangkan, 3) tanggapannya terhadap kegiatan ini $65 \%$ siswa yang diwawancari mengatakan sangat senag dan terbantu dalam menyelesaiakan soal HOTS, akan tetapi mereka mengatakan kurang tertarik karena masih kesulitan dalam mengerjakan soal.

Dari hasil wawancara dengan tim mahasiswa, dapat diketahui hal-hal berikut: 1) sebagian besar mahasiswa mendapatkan energy positif atau percaya diri karena menyadari kemampuannya sudah sampai mana, 2) mahasiswa banyak menemukan kendala dalam melaksanakan kegiatan ini, terutama dalam menemukan siswa-siswa yang susah sekali belajar tetapi mereka belum memeberikan bantuan yang maksimal kepada siswa, 3) problematika pembelajaran matematika yang ditemukan adalah kurangnya pemahaman konsep dasar oleh siswa dan juga motivasi yang rendah dan cenderung takut kepada pelajaran matematika, dan 4) masukan dari mahasiswa untuk program berikutnya adalah memepersiapkan waktu lebih banyak dan meminta kepada pihak madrsah untuk fokus pada proses pendampingan dengan mengesampingkan kegiatan lainnya supaya hasil pendampingan maksimal. 


\section{PEMBAHASAN}

Melihat hasil tes siswa dari pretest ke posttest mengalami peningkatan yang bisa dikatakan tergolong sedikit. Hal ini tentunya dipengaruhi oleh beberapa hal baik itu dari siswa sebagai peserta pendampingan dan tim yang memberikan pendampingan. Mengacu pada hasil wawancara dengan guru dan siswa, bisa dikatakan bahwa salah satu faktor penyebab peningkatan tergolong sedikit ini dikarenakan para siswa belum terbiasa dengan soal-soal berbasis HOTS. Baik guru maupun siswa cenderung melewati atau tidak mengerjakan jika ditemukan soal-soal yang sedikit sulit atau berbasis HOTS. Proses pembelajaran yang diberikan oleh guru yang hanya memberikan rumus kemudian contoh dan latihan sebagi pekerjaan rumah tentunya memberikan andil kurang terbiasanya guru dan siswa terhadap soal-soal berbasis HOTS ini. Hal ini sesuai dengan yang dikemukakan Riadi \& Retnowati (2014) bahwa pembelajaran metematika di Indonesia belum sepenuhnya focus pada pengembangan HOTS. Guru mengawali pembelajaran matematika hanya dengan mengenalkan definisi dan rumusrumus tanpa menghubungkannya dengan penyelesaian masalah dalam berbagai konteks. Selain itu juga guru juga belum melaksanakan pembelajaran yang menekankan keterampilan berpikir tingkat tinggi.

Persepsi siswa terkait dengan pelajaran matematika, bahwa pelajaran matematika itu sulit, tidak menarik, dan menakutkan tentunya juga menjadi salah satu factor penyebab kurangnya motivasi dan prestasi belajar mereka. Untuk mengatasi hal tersebut tentunya seorang guru harus mau dan mampu mengubah paradigma mengajar mereka untuk menghilangkan persepsi negative tersebut.

Mengacu pada hasil wawancara yang dilakukan pada mahasiwa, bahwa kegiatan pendampingan ini belum terlalu fokus dilakukan. Waktu pendampingan yang terbatas menjadi salah satu faktor penyebab peningkatan prestasi yang tergolong rendah. Seperti yang dikemukakan oleh Slameto (2010), prestasi belajar itu selain dipengaruuhi oleh faktor internal juga dipengaruhi oleh faktor eksternal diantaranya adalah manajemen waktu belajar tersebut.

\section{SIMPULAN}

Dengan dilakukan pendampingan, kemampuan siswa MTs dan MA NW Selayar menyelesaikan soal UN Matematika kategri HOTS mengalami peningkatan meskipun tergolong masih rendah. Kegiatan ini sangat bermanfaat bagi mahasiswa maupun sekolah tempat kegiatan yang tentunya juga meningkatkan silaturahmi antar organisasi yayasan Nahdlatul Wathan.

\section{PERNYATAAN PENULIS}

Artikel ini belum pernah di publikasikan di jurnal manapun. 


\section{ABSYARA: JURNAL PENGABDIAN PADA MASYARAKAT \\ BIDANG PENDIDIKAN, SAINS, DAN TEKNOLOGI}

Vol. 1 No. 1, Juli 2020, Hal. 10-15

\section{DAFTAR PUSTAKA}

Hamdi, Syukrul., Suganda Iin., \& Hayati, Nila. (2018). Developing higher-order thinking skill (HOTS) test instrument using Lombok local cultures as contexts for junior secondary school mathematics. REID (Research and Evaluation in Education), 4(2), 2018, 126-135.

King , F. J., Godson L., \& Rohani, F. (2013). Higher order thinking skills: definition teaching strategies, assessment. Center for Advancement of Leraning and Assesment.

Mandini, G. W \& Hartono. (2018). Analisis kemampuan menyelesaikan soal HOTS model TIMSS dan kepercayaan diri siswa sekolah menengah pertama. PYTHAGORAS: Jurnal Pendidikan Matematika, 13(2), 22018, 148-157.

Mullis, I. V. S.,Martin, M. O., Foy, P., \& Arora, A. (2015). TIMSS 2015 international result in mathematics. Chestnut Hill, MA: YIMSS \& PIRLS International Study Center.

OECD. (2019). Proramme For International Student Assessment (PISA Results From PISA 2018 Volume I-III. Paris: OECD Publishing

Rahmawati, S. (2016). Seminar hasil penilaian pendidikan. Seminar Hasil TIMSS 2015. Diambil dari Puspendik Kemendikbud.go.id/seminar/index.php?folder=hasil seminar puspendik2102016

Riadi, A. \& Retnowati, H. (2014). Pengembangan Perangkat Pembelajaran untuk meningkatkan HOTS pada kompetensi bangun ruang sisi datar. Phytagoras: Jurnal Pendidikan Matematika, 9(2), 126135.

Slameto (2010). Belajar dan Faktpr-faktor yang Mempengaruhinya. Jakarta: Rineka Cipta. 